JURNAL PARIWISATA BUDAYA, VOLUME 3, NOMER 2, TAHUN 2018

HALAMAN 9-14

\title{
Sekulerisasi Yoga dalam Pariwisata Bali
}

\author{
I Gede Sutarya \\ Institut Hindu Dharma Negeri Denpasar \\ sutarya@yahoo.com
}

\begin{abstract}
Yoga is a search for tourists in Bali tourism which is spread in some destinations in Bali such as in Ubud, Seminyak and Sanur. This search for yoga is a form of health search that is different from the purpose of yoga to achieve moksha (eternal happiness). This gap raises research questions about the form of yoga secularization in Bali tourism. This article reviews the form of yoga secularization in Balinese tourism according to the theory of historical materialism which states that the basic principle of change is matter. This article is based on qualitative research carried out in series in 2016 and 2017. The result is that the form of yoga secularization in Balinese tourism occurs through changes in orientation to health, changes in yoga techniques to healing techniques, exchange with money, and the use of science-technology. Changes are forms of secularization in yoga.
\end{abstract}

Keywords: Yoga, Secularization, Bali Tourism

\section{Pendahuluan}

Yoga menjadi salah satu atraksi pariwisata Bali. Pertumbuhan yoga ini tampak di Ubud, Sanur, Kuta (Seminyak), Sanur dan wilayah-wilayah lainnya. Perkembangan yang tajam tampak di Ubud. Hampir setiap hotel dan villa di Ubud memiliki tempat yoga. Hotel Chedi misalnya memiliki tempat yoga dengan pemandangan sawah di kawasan Goa Gajah, dekat Ubud. Ada juga tempat-tempat khusus untuk yoga, seperti Yoga Barn, Radiantly Alive dan studio-studio yoga lainnya, ada juga ashram yang menjadi pusat yoga seperti Ashram Munivara (Sutarya, 2016). Pertumbuhan yoga di hotel dan villa ini biasanya diasuh guru-guru yoga yang profesional.

Pertumbuhan yoga pada industry pariwisata memunculkan sebuah tipe yoga yang disebut dengan yoga kemersil. Yoga komersil memiliki berbagai tujuan seperti kesehatan, tubuh yang sexy, kecantikan dan lain sebagainya. Pertumbuhan yang paling umum adalah pertumbuhan yoga menjadi healing, atau teknik untuk kesehatan tubuh. Karena itu, pencarian yoga kebanyakan adalah untuk kesehatan bagi kalangan wisatawan. 
Pertumbuhan yoga dalam industri pariwisata ini tidak sesuai dengan esensi yoga dalam Hindu yang merupakan sumber utama yoga. Dalam agama Hindu, yoga adalah jalan untuk mencapai Samadhi, yang sering juga dijelaskan sebagai moksha (Titib, 2008:618). Akan tetapi, dalam pariwisata, yoga merupakan jalan untuk mencapai tujuan-tujuan duniawi, seperti kesehatan dan kesenangan yang diajarkan guru-guru yoga yang bertarif. Hal ini menjadi yoga yang merupakan proses spiritual menjadi sekuler. Kesenjangan ini menimbulkan pertanyaan penelitian tentang bentuk dan trend sekulerisasi yoga dalam pariwisata.

Sekulerisasi berasal dari kata sekuler yang berarti bersifat duniawi atau kebendaan (KBBI, 2018). Proses menjadikan yang spiritual menjadi duniawi disebut dengan sekulerisasi. Kepentingan yang bersifat duniawi itu berhubungan dengan kekayaan, kesehatan, dan kegembiraan. Sekulerisasi yoga biasanya berhubungan dengan kesehatan (Khanna dan Greeson, 2013, Brown, 2015). Sekulerisasi juga berbentuk teknik healing yang terjadi di Swedia (Hornborg, 2012). Sekulerisasi yoga ini dipraktikan dalam rumah sakit sebagai terapi pelengkap. Sekulerisasi yoga juga berbentuk branding (Borup, 2016).Sekulerisasi yoga dalam pariwisata belum pernah diteliti. Sutarya (2016) menemukan berbagai bentuk yoga dalam pariwisata, tetapi belum mengulas tentang bentuk dan trend sekulerisasi. Karena itu, artikel ini merupakan hal yang baru.

Artikel ini menggunakan pendekatan teori dari Karl Marx tentang materialism historis, yang menyatakan seluruh sejarah masyarakat berkembang berdasarkan tujuan-tujuan material. Teori ini dijelaskan Yacov Navicow (Scott, 2012:134) dalam pernyataan bahwa konflik manusia bermula dari persaingan fisiologis untuk bertahan dan memperoleh makanan. Teori ini relevan untuk menjelaskan bahwa perjalanan wisatawan untuk mengikuti yoga di Bali sebagai bentuk kegiatan materi, bukan spiritual. Artikel ini merupakan hasil dari penelitian berantai selama dua tahun (2016 dan 2017) yang menggunakan metode kualitatif melalui wawancara mendalam dengan pengelola, guru yoga dan wisatawan. Analisisnya juga menggunakan analisis kualitatif.

\section{Pembahasan}

Tujuan-tujuan materi (di luar spiritualitas) dalam pengelolaan yoga tergambar dalam pernyataan I Ketut Arsana, pengasuh Ashram Munivara, Ubud. Arsana menyatakan, kesehatan adalah pintu masuk wisatawan untuk mau belajar yoga. Wisatawan yang datang kebanyakan memiliki masalah kesehatan sehingga memerlukan berbagai solusi kesehatan. Setelah melakukan yoga untuk kesehatan mereka biasanya mulai sadar untuk meningkatkan spiritualitasnya. Karena itu, kesehatan merupakan pintu masuk spiritual.

Pernyataan Arsana ini dibenarkan wisman yang mengikuti yoga di tempat pelatihannya. Sutarya (2016:161) menjelaskan pengalaman Barber asal Australia dan Gudbjorg yang berlatih yoga di tempatnya Arsana. Mereka menyatakan memiliki masalah pada badan dan pikirannya. Karena itu, ia melakukan perjalanan ke Bali untuk berlatih yoga dengan Arsana. Dalam dua bulan, ia merasakan badan dan 
pikirannya mulai membaik. Karena itu, kesehatan menjadi tujuan dari pelatihan yoganya di Bali.

Guru Made Sumantra, guru yoga dari Markendya Yoga menyatakan hal serupa, bahwa wisatawan memiliki berbagai masalah kesehatan, yang biasanya berhubungan dengan stress. Yoga diajarkannya untuk menangani masalah tersebut, sehingga mereka tertarik untuk mengikuti yoga. Setelah mereka merasakan kesehatan, baru mereka melakukan latihan spiritual secara serius.Arsana menambahkan, ajaran spiritual sulit dipercaya jika tidak terbukti. Karena itu, kesehatan adalah bukti bahwa pelajaran spiritual itu efektif untuk kehidupan.

Kesehatan adalah tujuan material atau untuk kepentingan badan, tetapi badan, pikiran dan jiwa merupakan satu kesatuan. Pikiran yang tenang adalah awal dari kesehatan badan dan ketentraman jiwa. Hal ini merupakan logika yang digambarkan Arsana untuk menjadikan kesehatan sebagai pintu masuk spiritual, sebab dalam badan yang sehat akan ada pikiran yang tenang dan ketentraman jiwa. Karena itu, kesehatan badan menjadi pintu masuk dari Arsana dan Sumantra untuk melakukan perjalanan spiritual.

Hal ini tentu berbeda dari Yoga Sutra Patanjali yang pada Samadhi Pada Sloka 2 menyebutkan bahwa "yogas citta-vrtti-nirodhah" yang artinya yoga adalah usaha pengendalian pikiran (Taimni, 1986:6). Karena itu, pikiran adalah objek dari yoga. Gerakkan-gerakkan tubuh (asana) dan pengaturan napas (pranayama) adalah media untuk menjadikan pikiran mengendalikan tubuh dan napas. Pergeseran objek dari pengendalian pikiran ke kesehatan tubuh adalah pergeseran dengan tujuan-tujuan material.

Pergeseran ini dapat juga disebutkan sebagai selling spirituality (penjualan spiritual) seperti yang dinyatakan Carrete dan King (2005:x):

Selling spirituality examines the growing commercialization of religion in the form of popular notion of spirituality as it is found in education, health care, counselling, business training, management theory and marketing.

Pada konteks yoga di Bali, yoga dilakukan untuk pelayanan kesehatan sehingga merupakan bagian dari penjualan spiritual. Dalam penjualan tentu ada tarif yang diminta guru yoga dan yang dibayarkan oleh wisatawan.

Tarif latihan yoga di Ubud berkisar antara Rp.150 ribu s/d Rp.200 ribu per jam seperti yang terjadi pada pusat-pusat pelatihan yoga profesional di Radiantly A Live dan Yoga Barn. Arsana memiliki perlakuan yang berbeda dalam menentukan tarif ini. Wisatawan yang berlatih di rumahnya dikenakan tarif sekitar Rp.150 ribu per jam, tetapi wisatawan yang berlatih di Munivara Ashram digunakan mekanisme sumbangan yang paling rendah Rp.50 ribu.

Sumantra juga menggunakan sistem seperti itu kepada wisatawan. Menurut Sumantra, uang tidak menjadi tujuan kegiatannya. Ia ingin menyebarkan bahwa Bali merupakan pulau yang memiliki keunikan dalam hal yoga. Karena itu, wisatawan biasanya memberikan tarif yang bervariasi kepada dirinya. Kalau pun wisatawan 
tidak memberikan uang, ia tidak akan meminta. Karena itu, sistemnya mirip seperti sistem sumbangan.

Adanya pertukaran uang dalam pelatihan yoga ini merupakan salah satu syarat dari materialism dalam yoga. Uang yang ada dalam bentuk tarif adalah bentuk nyata dari pertukaran. Uang dalam bentuk sumbangan adalah bentuk tidak nyata dari proses pertukaran. Sumbangan atau yang disebut dengan dana punia dibenarkan dalam tradisi Bali. Pendeta dan guru bisa menggunakan sumbangan untuk kehidupannya.

Atharvaveda 9.5.14 menyatakan seseorang yang memberikan daksina (sumbangan) kain dan emas akan mendapatkan kebaikan di antariksa dan pertiwi (Somvir, 2013:195). Hal ini menunjukkan bahwa seorang murid diharapkan memberikan sumbangan kepada guru. Praktik seperti ini terjadi dalam tradisi pengajaran yoga. Karena itu, sumbangan merupakan syarat dalam tradisi perguruan yang tidak bisa disebutkan sebagai pertukaran.

Syarat adanya uang dalam beberapa kasus tidak mengena untuk disebutkan sebagai pertukaran, tetapi orientasi yoga untuk kesehatan dapat disebutkan sebagai orientasi non-spiritual. Karena itu, walaupun uang terjadi dalam bentuk tradisi keagamaan (melalui sumbangan) tetapi motifnya untuk mendapatkan kesehatan (non-spiritual) maka itu bisa disebutkan sebagai pertukaran. Karena itu, ini memenuhi syarat sebagai pertukaran dalam dunia sekuler.

Bentuk sekulerisasi yoga menjadi kesehatan tidak hanya terjadi dalam pariwisata di Ubud, Bali. Honrborg (2012:406) menyatakan bentuk-bentuk spiritualitas menjadi teknik healing hal yang populer terjadi di Swedia. Perubahan bentuk ini merupakan proses sekulerisasi. Proses sekulerisasi ini juga menggunakan ilmu pengetahuan dan teknologi sebagai bahan untuk menjelaskan dogma-dogma ritual (Heath, 2012:410). Dalam yoga penggunaan teknologi dan ilmu pengetahuan untuk menjelaskan yoga juga terjadi.

Arsana misalnya sangat ahli menjelaskan tentang manfaat kesehatan dari menu makanan vegetarian yang diberikan kepada wisatawan. Dia juga ahli menjelaskan berbagai hubungan setiap gerakkan yoga dengan kesehatan. Hal itu juga dilakukan Sumantra yang juga menjelaskan berbagai praktiknya dalam yoga dengan ilmu pengetahuan. Arsana menyatakan, pengetahuan terhadap ilmu kesehatan mendukung berbagai penjelasannya tentang yoga, sebab wisatawan hanya dapat diyakinkan dengan ilmu pengetahuan.

Oleh karena itu, sekulerisasi yoga dalam pariwisata Bali terjadi pada perubahan orientasi dari spiritual ke kesehatan, perubahan teknik spiritual menjadi teknik healing, penggunaan ilmu pengetahuan untuk menjelaskan yoga dan terjadinya pertukaran dengan uang. Pertukaran dengan uang ini terjadi dalam dua bentuk, yaitu melalui tarif dan sumbangan. Pertukaran dengan uang melalui sumbangan sesuai 
dengan tradisi tetapi motifnya adalah untuk mendapatkan kesehatan, sehingga bisa disebutkan sebagai sekulerisasi.

\section{Simpulan}

Pencarian wisatawan terhadap yoga dalam pariwisata Bali menimbulkan perubahan bentuk yoga menjadi teknik healing, sehingga orientasi yoga para wisatawan adalah kesehatan. Perubahan orientasi ini merupakan salah satu bentuk sekulerisasi yoga. Sekulerisasi ini tidak hanya terjadi di Bali, tetapi juga terjadi di berbagai negara di mana yoga merupakan salah satu bentuk terapi. Perubahan bentuk ini menimbulkan perubahan hubungan guru dan murid yang sudah dipengaruhi uang. Uang dalam proses ini terjadi dalam dua bentuk, yaitu tarif dan sumbangan. Sumbangan sesuai dengan tradisi tetapi motif dari sumbangan tersebut adalah untuk mendapatkan kesehatan. Motif ini adalah motif sekuler sehingga bisa disebut sebagai sekulerisasi.

Sekulerisasi berikutnya terjadi pada penggunaan ilmu pengetahuan dan teknologi untuk menjelaskan yoga sehingga bisa diterima wisatawan. Penggunaan ilmu pengetahuan ini merupakan bentuk dari sekulerisasi yoga. Karena itu, guru yoga harus memiliki pengetahuan sekuler untuk menjelaskan yoga, sehingga yoga kerap sudah menjadi hybrid antara pengetahuan lokal dengan pengetahuan modern. Proses ini tidak hanya terjadi pada pariwisata Bali, tetapi terjadi juga di berbagai negara seperti Swedia. 
Daftar Pustaka

Borup, John. 2016. Branding Buddha-Medialized and Commodified Buddhism as Cultural Narrative. Journal of Global Buddhism, 17(41-45).

Brown, Candy Gunther. 2015. Integrative Medicine in Hospital: Secular or Religious. Society, 52, 5 (462-468).

Carrete, Jeremy R dan Richard King. 2005.Selling Spirituality, the Silent Takeover of Religion. London: Routledge Taylor \& Francis.

Hornborg, Anne-Christine. 2012. Designing Rites to Re-enchant Secularized Society: New Varieties of Spiritualized Therapy in Contemporary Sweden. Springer, page 402-418.

KBBI. 2018. Kamus Besar Bahasa Indonesia. https://kbbi.kemdikbud.go.id.

Khanna, Surbhi dan Jeffrey M Greeson. 2013. A Narrative Review of Yoga and mindfulness as Complementary therapies for addiction. Kindleton, 21 (3).

Scot, John. 2012. Teori Sosial Masalah-Masalah Pokok dalam Sosiologi. Yogyakarta: Pustaka Pelajar.

Somvir. 2013. 108 Mutiara Veda II. Denpasar: Bali-India Foundation.

Sutarya, I Gede. 2016. Spiritual Healing dalam Pariwisata Bali. (Disertasi). Denpasar: Universitas Udayana.

Taimni, I.K. 1986. The Science of Yoga. London: The Theosophical Publishing House.

Titib, I Made. 2008. Purana, Sumber Ajaran Hindu. Denpasar: Paramita. 